$2021,22(4)$, pp. 344-352, DOI:10.18038/estubtda. 806222

RESEARCH ARTICLE

\title{
HIGHLY SENSITIVE LABEL-FREE ELECTROCHEMICAL DETECTION OF HEAT SHOCK PROTEIN WITH LOW-COST SCREEN-PRINTED ELECTRODES
}

\section{Fatma DOGAN GUZEL ${ }^{1 \text {, * (D) , Iremnur AKCAKOCA }}{ }^{2}$ (D) , Hamed GHORBANPOOR ${ }^{1,3}$ (iD), Araz Norouz DIZAJI ${ }^{1}$ (D), Yasin OZTURK ${ }^{2}$ (i) , Ewen O. BLAIR ${ }^{\text {(iD), Tanil KOCAGOZ }}{ }^{5,6}$ (iD), Damion K CORRIGAN ${ }^{4}$ (i) , Huseyin AVCI ${ }^{7}$}

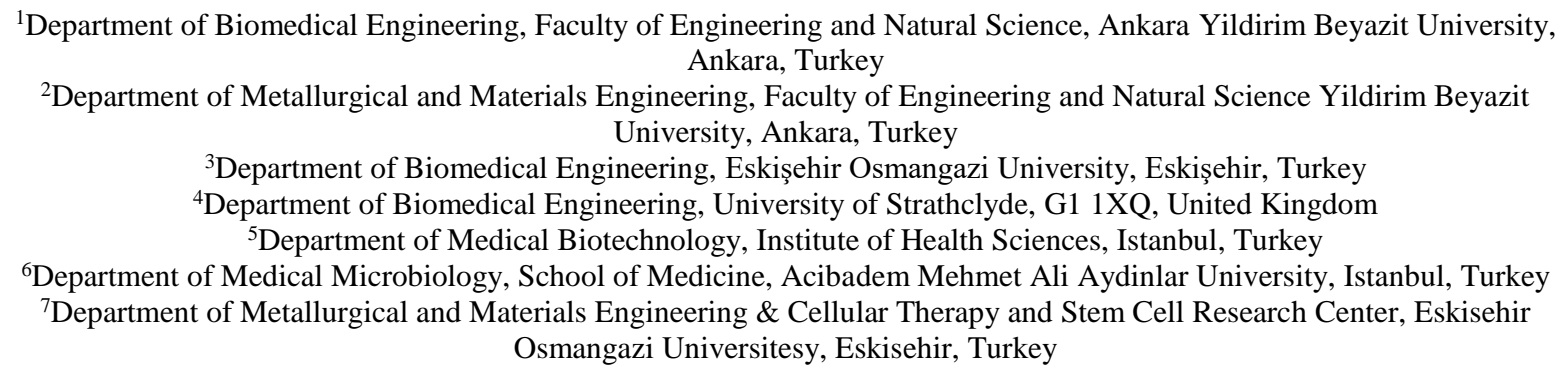

\begin{abstract}
Heat shock proteins (HSPs) are produced when organisms are exposed to various environmental stress conditions such as extreme temperatures, light, and toxins. It is a known fact that in bacteria which have the HSP gene ( $h s p$ ), antibiotics can trigger the expression of these proteins. However, the response of HSP genes to antibiotics has not been fully clarified in the literature, with studies still ongoing. In this work, a novel method of detecting heat shock protein 65 (HSP65) was investigated using electrochemical impedance spectroscopy (EIS) due to its sensitivity and selectivity. To do so, a specific HSP65 probe and target were designed and their hybridization behaviour was studied using low-cost screen-printed electrodes (SPEs). Cyclic voltammetry was performed to analyse surface characteristics of the SPEs and the performance of the electrodes was tested using EIS, by measuring changes in the charge transfer resistance upon probe binding and target hybridization. Increases in charge transfer resistance were measured and observed to be in-line with literature. Based on these results, the designed HSP65 probe was confirmed to bind the target sequence and proved that the EIS can be effectively used to detect HSP65 label-free. Results presented here could lead to development of antibiotic susceptibility assays based on $h s p$ genes in future and provide a quicker test for the detection of many slow-growing bacteria.
\end{abstract}

Keywords: Electrochemical impedance spectroscopy (EIS), Screen printed electrodes (SPEs), Heat Shock Proteins (HSPs), DNA sensor, Mycobacteria

\section{INTRODUCTION}

Mycobacterium tuberculosis (MT) is an extremely hazardous species of Mycobacteria Spp., and contains over 60 genes [1]. Among them are Heat Shock Protein (HSP) genes, which respond to stresses at a molecular level very quickly through increased transcription of mRNA [2]. In particular, the $h s p 65$ gene encoding the HSP65 protein is known as one of the preserved gene sequences of Mycobacterium [3]. Based on initial findings, the expression of this protein was associated with temperature stress, leading to its name "heat shock protein". However these proteins are not only dependent on temperature stresses, but can also be expressed in response to changes in $\mathrm{pH}$ and salt balance [4]. When bacteria are exposed to stresses such as these, chaperone proteins are synthesized as a result of an increased expression of the hsp65 gene, which induces the folding of proteins to prevent their denaturation. In

*Corresponding Author: fdogan@ybu.edu.tr

Received: 14.10.2020 Published: 29.12.2021 
addition, another factor that has a tremendous effect on the expression of HSP genes is the presence of antibiotics in the environment. Increases in expression of the genes controlling HSP due to the presence of antibiotics have been reported by many groups in the literature [5]. The exact mechanism for the emergence of HSP and the HSP65 proteins involved is still unknown and there is no clear list of which antibiotics activate these genes during treatment [6]. HSP65 is of great importance to researchers and clinicians alike, as it can be used as an early diagnostic biomarker in the treatment of tuberculosis. There have been a few reports on the detection of hsp65 gene and/or HSP65 protein in the literature. For example, Mudaliar et al., accomplished the detection of tuberculous meningitis using Enzyme-Linked ImmunoSorbent Assay (ELISA) from actual tuberculous meningitis patients [7], and Senna et al., tested the possibility of $h s p 65$ gene sequencing as a method to identify mycobacteria and also analysed the genetic variability of bacteria using Polymerase Chain Reaction (PCR) [8]. Most of these methods are based on ELISA test and/or PCR-based microbiology tests. In general, there seems to be an urgent need to find a way to detect this specific protein and other HSPs label-free, PCR-free and with high sensitivity, since its quick expression in slow-growing bacteria like MT can provide an excellent way for the early diagnosis and the treatment of the infection. The mycobacterium family is very well-known as a hard growing species of bacteria that can causes challenges for the early detection and further treatment efforts. Recently, electrochemical sensors have been explored by many groups for rapid detection of these bacteria as an alternative to common microbiological methods $[3,9,10]$.

Electrochemical sensors provide label-free, sensitive detection of biomolecules [11-15]. One of the most sensitive electrochemical method used for biomolecular detection is Electrochemical Impedance Spectroscopy (EIS) [12,16]. EIS-based DNA sensors work without the need of labels or PCR amplification. This feature makes the sensor system simpler, cheaper, faster and more convenient [1721]. The mechanism of DNA based electrochemical biosensors is based on two fundamental consecutive steps: self-assembled monolayer (SAM) formation of DNA probe on the surface of electrode (immobilization) and then DNA target binding onto the probe (hybridization) [13,22]. Probes carry the specific gene sequence that matches the DNA target sequence of interest. EIS can then be used to measure changes at the electrode interface induced by DNA hybridization [20].

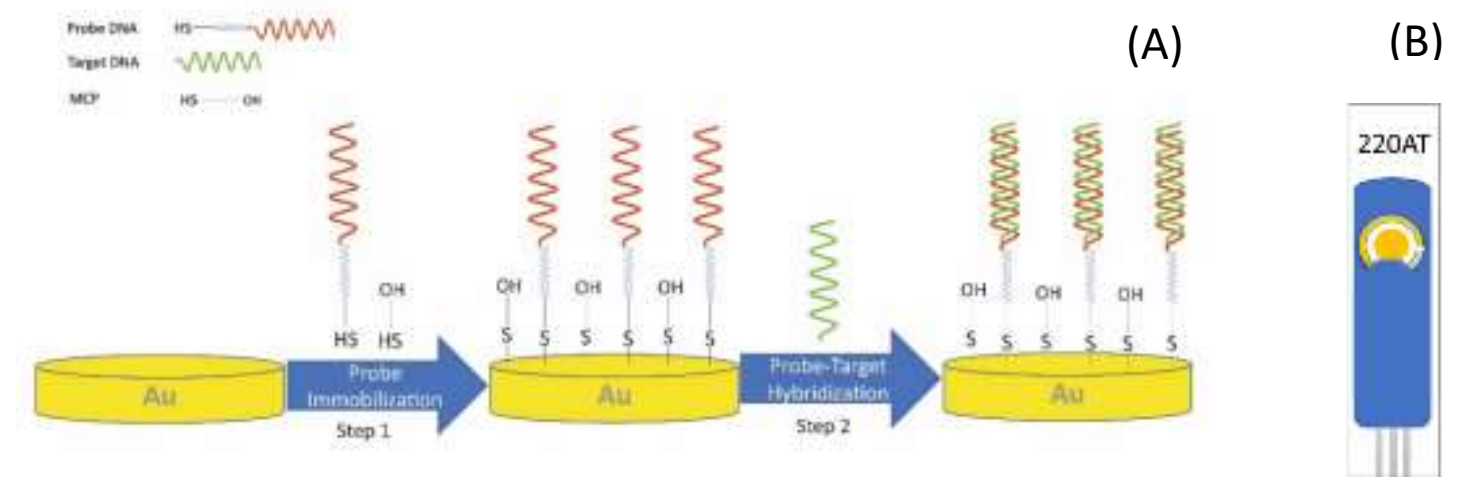

Figure 1. (A) Schematic of the working mechanism of DNA-based electrochemical biosensors. The bare gold surface is covered by immobilized hsp65 probe DNA and 3-Mercapto-1-propanol, used for backfilling, followed by hybridization upon incubation with the hsp65, (B) Schematic of the SPE.

In this study, we report the first electrochemical detection of the $h s p 65$ gene using EIS. To do so, a HSP65 DNA probe was designed and hybridization to it was investigated using complementary and non-complementary target oligonucleotides. The working mechanism of the sensor is shown in Figure 1A. Low-cost 220AT SPEs were used as an interface for the EIS experiments and proved that the designed sensor works with high sensitivity and selectivity towards the hsp65 gene target. 


\section{MATERIALS AND METHODS}

\subsection{Materials and Apparatus}

The commercially available 220AT gold SPEs with silver reference and gold counter electrodes were purchased from Metrohm (Herisau, Switzerland). $\mathrm{K}_{4}\left[\mathrm{Fe}(\mathrm{CN})_{6}\right] \cdot 3 \mathrm{H}_{2} \mathrm{O}$ (potassium ferrocyanide), $\mathrm{K}_{3}\left[\mathrm{Fe}(\mathrm{CN})_{6}\right]$ (potassium ferricyanide), 3-Mercapto-1-propanol (MCP), tris(2-carboxyethyl) phosphine (TCEP), phosphate buffered saline (PBS), sulfuric acid $\left(\mathrm{H}_{2} \mathrm{SO}_{4}\right)$ were purchased from Sigma-Aldrich (USA). A PalmSens4 potentiostat (PalmSens, Houten, Netherlands) was used to carry out electrochemical measurements. The designed $h s p 65$ probe and complementary target were obtained from BMLabosis (Turkey) and the non-complementary target was obtained from Sigma-Aldrich. Table 1 shows the probe and the target sequences used in the experiment.

Table 1. DNA sequences used in the experiments.

\begin{tabular}{ll}
\hline Function & Sequence \\
\hline Probe & 5'- Thiol-C6-(HEG-Spacer) AAAGAGGTCGCCAAGAAGAC -3' \\
Complementary Target & 5'-GTCTTCTTGGCGACCTCTTT-3' \\
Non-complementary Target & 5'-CGGGATGCATGTCTTGTGGT-3' \\
\hline
\end{tabular}

\subsection{Electrode Functionalization}

The electrode surface was initially cleaned in $0.1 \mathrm{M} \mathrm{H}_{2} \mathrm{SO}_{4}$ using Cyclic Voltammetry (CV) (between $0.05 \mathrm{~V}$ and $0.9 \mathrm{~V}$ potentials, at $0.1 \mathrm{~V} / \mathrm{s}$ ) until the increasing of the gold reduction peak stabilizes. The electrodes were then rinsed with deionized (DI) water to remove $\mathrm{H}_{2} \mathrm{SO}_{4}$, then dried with nitrogen gas. Electrodes were then incubated overnight with $3 \mu \mathrm{M}$ probe DNA prepared in $15 \mu \mathrm{M}$ TCEP and $1 \mathrm{xPBS}$. Afterwards electrodes were rinsed with DI water for $10 \mathrm{~s}$ and backfilled with MCP solution, prepared using $1 \mathrm{mM}$ MCP in $5 \mathrm{mM}$ TCEP and 1xPBS for $1 \mathrm{~h}$. After the backfilling, the electrodes were rinsed in DI water for 10 second. Finally, the electrodes were incubated with $500 \mathrm{nM}$ target DNA for $1 \mathrm{~h}$ at room temperature, according to the protocol developed by Blair et al.[21]. Following this, the electrodes were rinsed using 5\% PBS solution for 20 second. EIS measurement were taken before and after all incubation steps and all the experiments were repeated at least 3 times.

\subsection{Electrochemical Measurements}

$\mathrm{CV}$ measurements were taken between the potentials $-0.25 \mathrm{~V}$ and $0.5 \mathrm{~V}$ at $0.1 \mathrm{~V} / \mathrm{s}$. All measurements were performed in $1 \mathrm{mM} \mathrm{Fe}[\mathrm{CN}]_{6}{ }^{3-} / \mathrm{Fe}[\mathrm{CN}]_{6}{ }^{4-}$ solution and EIS with a frequency range between 100 $\mathrm{kHz}$ and $0.1 \mathrm{~Hz}$. Impedance data was fitted using the Randles equivalent circuit to determine the charge transfer resistance $\left(\mathrm{R}_{\mathrm{CT}}\right)$ [22]. $\mathrm{R}_{\mathrm{CT}}$ values were calculated from statistical analysis of the impedance plot using the PS Trace software.

\section{RESULTS AND DISCUSSIONS}

The Hsp gene is known as one of the conserved gene sequences of Mycobacterium Spp. There are several studies in literature for the EIS-based $h s p 70$ gene detection. For examples, Demirbakan et al. determined the immobilization behavior of $h s p 70$ and then analyzed real human blood serum samples on fullerene C60 as electrode by using EIS [23]. Sun et al., recently reported an electrochemical immunosensor which employed porous graphene as the electrode material for the detection of $h s p 70$ [24]. Aguilar et al., developed an assay that detected immobilization and hybridization of Cryptosporidium parvum HSP70 mRNA using gold macrochip electrodes [25]. To the best of our knowledge, there are no electrochemical analysis approaches for the hsp65 gene. 
In this study, we developed an electrochemical approach to detect the hsp65 gene with high sensitivity and selectivity, for the first time in literature. To do so, EIS was chosen as the label-free method of detection. The electrodes in our study were 220AT gold SPEs, which have a $4 \mathrm{~mm}$ diameter working electrode with a silver reference electrode surrounding it, as shown in Figure 1 B. Cleaning the electrodes and characterization of the cleaning procedure were actualized using $\mathrm{CV}$ under $0.1 \mathrm{M} \mathrm{H}_{2} \mathrm{SO}_{4}$. $\mathrm{CV}$ is an electrochemical method which applies a changing potential and analyses the resultant current, enabling characterisation of the electrode through known reduction and oxidation reactions. It is frequently used for surface cleaning and understanding of surface properties of electrodes [26]. The electrodes were cycled between $-0.05 \mathrm{~V}$ and $+0.9 \mathrm{~V}$ at $0.1 \mathrm{~V} / \mathrm{s}$ until the current peaks remains unchanging, as shown in Figure 2A. Commonly the cycling voltage for cleaning electrode surfaces in $\mathrm{CV}$ measurements ranges from $-0.5 \mathrm{~V}$ to $1.75 \mathrm{~V}$, but this potential could be changed according to process properties and voltammetry graph [21]. Surface characterization of the electrodes was performed using $1 \mathrm{mM} \mathrm{Fe}[\mathrm{CN}]_{6}{ }^{3-} / \mathrm{Fe}[\mathrm{CN}]_{6}{ }^{4-}$ solution, after the cleaning process. At this measurement stage, electron transfer which occurred at the electrode-electrolyte interface was examined [27]. The quality of cleaning was evaluated from the reduction- oxidation behaviour at the electrode surface. The cleanliness of the surface was evaluated by measuring the peak-to-peak of the reduction and oxidation reactions. Ideally this separation should be as near as possible to the theoretical value of $57 \mathrm{mV}$, as shown in Figure 2B. Butterworth et al. reported peak-to-peak separation for SPEs between 70-90 mV [28]. In this study, a peak-to-peak separation of approximately $80 \mathrm{mV}$ was found, suggesting the cleaning process was successfully carried out.
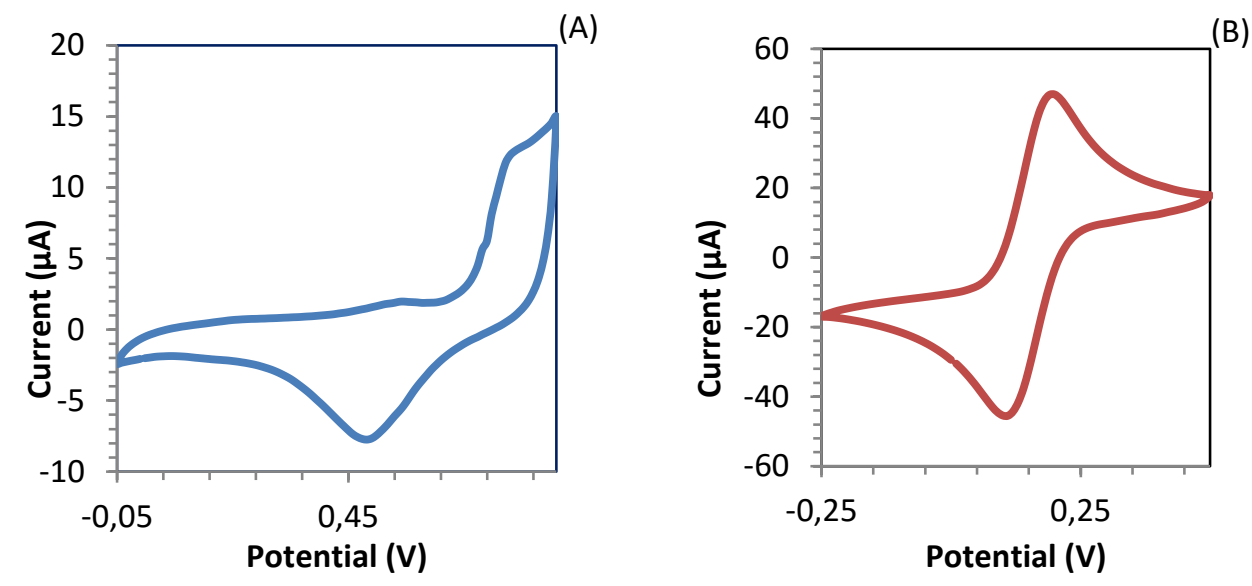

Figure 2. (A) Cyclic voltammograms in $0.1 \mathrm{M} \mathrm{H}_{2} \mathrm{SO}_{4}$ solution for surface cleaning, (B) The characteristic cyclic voltammograms in $1 \mathrm{mM} \mathrm{Fe}[\mathrm{CN}]_{6}^{3-} / \mathrm{Fe}[\mathrm{CN}]_{6}^{4-}$ for surface characterization before the probe immobilization.

After the characterization of SPEs with CV and the confirmation of the cleaning, the bare gold electrode surface was functionalized with HSP65 probe for 16-24 hours [29]. This functionalization was characterized using Fourier Transform Infrared Spectrophotometry (FTIR) (UNAM, Turkey) and illustrated in Figure S-1. FTIR results prove that the probe DNA was attached to the electrode surface. The wavenumber of the chemical bonds observed after the probe DNA functionalization are also listed in Table S-1. Following this, the electrodes were further functionalised with MCP solution to backfill the gold surface for 1 hour [30]. EIS was performed directly after this immobilization procedure to characterise the functionalisation. Then, the hybridization step was performed by incubating $h s p 65$ target on the gold electrode surface, which was already immobilized with HSP65 probe and MCP. After the incubation process for 1 hour, post-target EIS measurements were performed. As a result of the hybridization, an increase in negative charge was observed at the electrode surface. With this increase of negative charge, the charge transfer of the negatively charged redox molecules was hindered in the solution, causing a change in the $\mathrm{R}_{\mathrm{CT}}$, measurable by EIS as reported previously [29, 31]. In EIS, impedance behaviour is modelled by solution resistance $\left(R_{s}\right)$, constant phase element $(C P E), R_{C T}$ and Warburg impedance (W), and these are expressed by Randles circuit (Figure 3A) and Nyquist plot is 
illustrated by these elements (Figure 3B) [32]. Although the Randle's circuit typically employs a capacitor, to model the double layer capacitance, it is often necessary to substitute it for CPE to account for more complex electrode surfaces found with SPEs and bio-functionalised electrodes.

Three different EIS measurements (pre-probe, post-probe and post-target) were performed using complementary and non-complementary target DNA sequences. After cleaning, the $\mathrm{R}_{\mathrm{CT}}$ values of the surfaces were measured before the probe incubation in the $\mathrm{Fe}[\mathrm{CN}]_{6}{ }^{3-} / \mathrm{Fe}[\mathrm{CN}]_{6}{ }^{4-}$ solution. The quality of the cleaning affects the functionalization results during the experiment. After determining the success of the cleaning, HSP65 probes were attached to the electrode surface with thiol bonds [33], and immobilization was clearly observed with an increase in the measured $\mathrm{R}_{\mathrm{CT}}$ value. In the last experimental stage, $\mathrm{R}_{\mathrm{CT}}$ value further increased after complementary target hybridization for SPEs. Figure 3B demonstrates the EIS graph and signal changes. Pre-probe, post-probe, and post-target measurements were illustrated as blue, red, and green respectively. $\mathrm{R}_{\mathrm{CT}}$ value was calculated $615 \Omega$ before probe immobilization, and $1112 \Omega$ after. This further increased to $1500 \Omega$ after complementary DNA hybridization. A two-tailed t-test was performed to compare complementary and non-complementary target hybridisation signals and $p$-values was calculated to be $p \leq 0.004, p \leq 0,003, p \leq 0,0001$ for pre-probe, post probe and post target, respectively. The outcome of the t-tests proved that there were statistically significant differences.

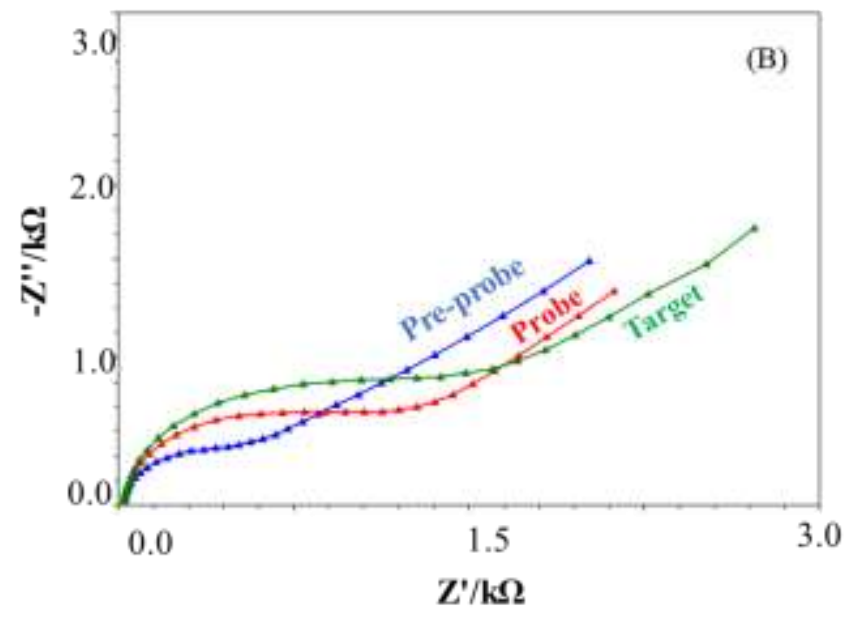

Figure 3. (A) Randles equivalent circuit, (B) The EIS spectrums taken after pre-probe, probe and target incubations.

To determine the sensitivity of the sensor, the sensor was challenged with the non-complementary target DNA sequence. The signal change was found to be $138 \%$ for complementary target and $60 \%$ for noncomplementary target, as depicted in Figure 4. Signal change for the non-complementary DNA hybridization was lower as expected, since the probe and target do not correctly match to each other. As a result, we proved that the HSP65 probe and targets were compatible with each other and the sensor was sensitive to the detection of complementary binding of the DNA probe and target. The changes in resistance values measured in the experimental stages reveals that the experiment was successfully completed at $\mathrm{nM}$ detection level [34]. 


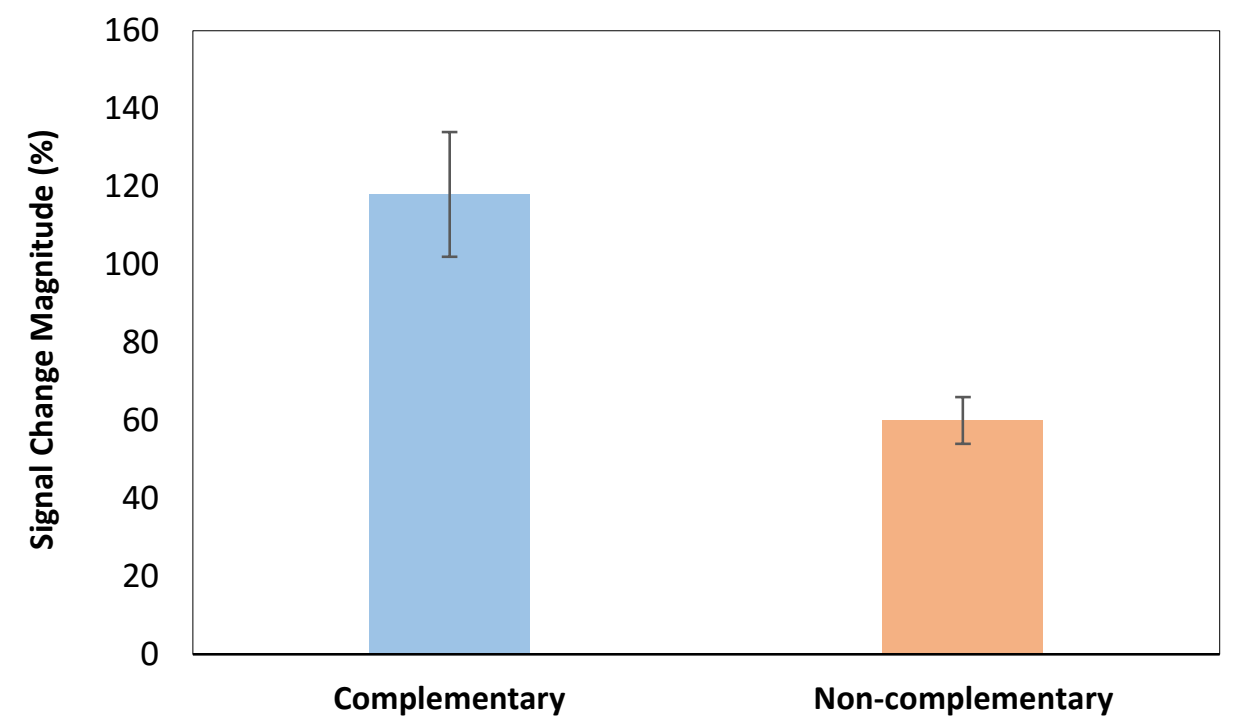

Figure 4. Signal change upon complementary and non-complementary target DNA hybridizations $(N=4)$.

It is clear that the hybridization and selective detection of HSP65 is possible with the methodology described above, with the accuracy of the results supported by t-tests. Given the incubation step of an hour and the post-target measurement is around 5 minutes, the total time-to-result is around 65 minutes. Although already faster than many MT assays, this can be further shortened by optimising the time of the incubation step. The next stage of development for this assay is its optimisation and validation with complex samples of real Mycobacteria. The sensitivity can also be improved through incorporation with microfluidic channels, miniaturisation of the sensing element, and with the use of nanostructured surfaces.

\section{CONCLUSION}

In this study, we report a new way to detect the $h s p 65$ gene label-free and PCR-free using a low-cost electrochemical set up. EIS was chosen as the method owing to its capability to monitor small changes in the analyte, and the commercially available 220AT gold SPEs as an electrode for its low-cost. The detection procedure described herein includes the probe design, cleaning procedure of the electrodes and EIS measurements upon the binding of probe and target DNA sequences on the electrode surface. The cleaning performance of the electrode plays a key role in the quality of the experiment and the method used here was presented and characterised. Immobilization and complementary hybridization of HSP65 probe and target, were confirmed successfully after increases in $\mathrm{R}_{\mathrm{CT}}$ in EIS values, respectively. Non-complementary testing was also performed to show the sensitivity of our system towards the target of our interest at $\mathrm{nM}$ detection level. We believe that this sensor platform, using the designed HSP65 probe in this study, can be widely used to quickly and accurately detect antibioticresistant Mycobacterium tuberculosis infections in future studies.

\section{ACKNOWLEDGEMENTS}

This study was conducted in the frame of Newton Katip Celebi Fund between Turkey and UK and supported by Turkish Scientific and Technological Council (TUBITAK) under the grant number of 217S793. Authors would like to thank I. A. Ince for useful discussions. 


\section{CONFLICT OF INTEREST}

The authors stated that there are no conflicts of interest regarding the publication of this article.

\section{REFERENCES}

[1] Garred P, Brygge K, Sorensen CH, Madsen HO, Thiel S, Svejgaard A. Mycobacteria in water. J Appl Bacteriol 1984; 57: 193-211.

[2] Beere HM. "The stress of dying": The role of heat shock proteins in the regulation of apoptosis. J Cell Sci 2004; 117: 2641-2651.

[3] Nguyen L. Antibiotic resistance mechanisms in M. tuberculosis: an update. Arch Toxicol 2016; 90: 585-1604.

[4] Hendrick JP, Hartl F. Functions of Heat-Shock 1993.

[5] Tran TD, Kwon HY, Kim EH, Kim KW, Briles DE, Pyo S, Rhee DK. Decrease in penicillin susceptibility due to heat shock protein ClpL in Streptococcus pneumoniae. Antimicrob Agents Chemother 2011; 55: 2714-2728.

[6] Briffotaux J, Liu S, Gicquel B. Genome-wide transcriptional responses of Mycobacterium to antibiotics. Front Microbiol 2019; 10: 1-14.

[7] A. Mudaliar AV, Kashyap RS, Purohit HJ, Taori GM, Daginawala HF. Detection of $65 \mathrm{kD}$ heat shock protein in cerebrospinal fluid of tuberculous meningitis patients. BMC Neurol 2006; 6: 17 .

[8] Senna SG, Battilana J, Costa JC, Silva MG, Duarte RS, Fonseca LS, Suffys PN, Bogo MR. Sequencing of hsp65 gene for identification of Mycobacterium species isolated from environmental and clinical sources in Rio de Janeiro, Brazil. J Clin Microbiol 2008; 46: 38223825 .

[9] Onat Akbulut S, Ghorbanpoor H, İpteç BÖ, Butterworth A, Avcıŏlu G, Kozacı LD, Topateş G, Corrigan DK, Avci H, Guzel FD. Impedance testing of porous Si3N4 scaffolds for skeletal implant applications SN Appl Sci 2020; 2: 823-828.

[10] Keighley SD, Li P, Estrela P, Migliorato P. Optimization of DNA immobilization on gold electrodes for label-free detection by electrochemical impedance spectroscopy. Biosens Bioelectronvol 2008; 23: 1291-1297.

[11] Guzel FD, Citak F. Development of an on-chip antibiotic permeability assay with single molecule detection capability. IEEE Trans Nanobioscience 2018; 17: 155-160.

[12] Malhotra S, Verma A, Tyagi N, Kumar V. Biosensors: principle, types and applications. Int J Adv Res Innov Ideas Educ 2017; 3: 3639-3644.

[13] Baselt DR, Lee GU, Natesan M, Metzger SW, Sheehan PE, Colton RJ. A biosensor based on magnetoresistance technology. Biosens Bioelectron 1998; 13: 731-739. 
[14] Yang R, Jin J, Chen Y, Shao N, Kang H, Xiao Z, Tang Z, Wu Y, Zhu Z, Tan W. Carbon nanotubequenched fluorescent oligonucleotides: probes that fluoresce upon hybridization. J Am Chem Soc 2008; 130: 8351-8358.

[15] Kaur J, Ghorbanpoor H, Öztürk Y, Kaygusuz Ö, Avc1 H, Darcan C. Trabzon L, Güzel FD. Onchip label- free impedance- based detection of antibiotic permeation. IETNanobiotechnol 2021; $1-7$.

[16] Niu SY, Li QY, Ren R, Zhang SS. Enzyme-enhanced fluorescence detection of DNA on etched optical fibers. Biosens Bioelectron 2009; 24: 2943-2946.

[17] Wilson JN, Teo YN, Kool ET. Efficient quenching of oligomeric fluorophores on a DNA backbone. J Am Chem Soc 2007; 129: 15426-15427.

[18] Randviir EP, Banks CE. Electrochemical impedance spectroscopy: an overview of bioanalytical applications. Anal Methods 2013; 5: 1098-1115.

[19] Blair EO, Corrigan DK. A review of microfabricated electrochemical biosensors for DNA detection. Biosens Bioelectron 2019; 134: 57-67.

[20] Liu J, Cao Z, Lu Y. Functional nucleic acid sensors. Chem Rev 2009; 109: 1948-1998.

[21] Blair EO, Hannah S, Vezza V, Avcı H, Kocagoz T, Hoskisson PA, Güzel FD, Corrigan DK. Biologically modified microelectrode sensors provide enhanced sensitivity for detection of nucleic acid sequences from Mycobacterium tuberculosis. Sensors and Actuators Reports. Sens. Actuator report 2020; 2: 100008.

[22] Huang Y, Bell MC, Suni II. Impedance biosensor for peanut protein Ara h 1. Anal Chem 2008; 80: 9157-9161.

[23] Demirbakan B, Sezgintürk MK. A novel immunosensor based on fullerene C60 for electrochemical analysis of heat shock protein 70. J Electroanal Chem 2016; 783: 201-207.

[24] Sun B, Cai J, Li W, Gou X, Gou Y, Li D, Hu F. A novel electrochemical immunosensor based on PG for early screening of depression markers-heat shock protein 70. Biosens Bioelectron 2018; 111: 34-40.

[25] Aguilar ZP, Fritsch I. Immobilized Enzyme-Linked DNA-Hybridization Assay with Electrochemical Detection for Cryptosporidium p arvum hsp70 mRNA. Anal Chem 2003; 75 : 3890-3897.

[26] PS J, Sutrave DS. A brief study of cyclic voltammetry and electrochemical analysis. Int J ChemTech Res 2018; 11: 77-88.

[27] Dizaji AN, Ali Z, Ghorbanpoor H, Ozturk Y, Akcakoca I, Avci H, Guzel FD. Electrochemicalbased "antibiotsensor' for the whole-cell detection of the vancomycin-susceptible bacteria. Talanta. 2021 Nov 1;234:122695.

[28] Butterworth A, Blues E, Williamson P, Cardona M, Gray L, Corrigan DK. SAM composition and electrode roughness affect performance of a DNA biosensor for antibiotic resistance. Biosens 2019; 9: 1-12. 
[29] Rashid JIA, Yusof NA. The strategies of DNA immobilization and hybridization detection mechanism in the construction of electrochemical DNA sensor: A review. Sens Biosensing Res 2019; 16: 19-31.

[30] Bedford E. Gold surface nanostructuring for separation and sensing of biomolecules. Doctoral dissertation 2017.

[31] Guzel FD, Ghorbanpoor H, Dizaji AN, Akcakoca I, Ozturk Y, Kocagoz T, Corrigan DK, Avci H. Biotechnol Appl Biochem 2020; doi:10.1002/bab.2037.

[32] Lisdat F, Schäfer D. The use of electrochemical impedance spectroscopy for biosensing. Anal Bioanal Chem 2008; 391: 1555-1567.

[33] Park JY, Park SM. DNA hybridization sensors based on electrochemical impedance spectroscopy as a detection tool. Sensors 2009; 9: 9513-9532.

[34] Drummond TG, Hill MG, Barton JK. Electrochemical DNA sensors. Nat Biotechnol 2003; 1: 1192-1199. 